\title{
TECHNOLOGICAL IMPERATIVES OF YOUNG PEOPLE IN FINLAND - COMPETENCES AND OPPORTUNITIES NEEDED FOR DIGITAL AGENCY
}

\author{
Sari Tuuva-Hongisto ${ }^{1}$, Kristiina Korjonen-Kuusipuro ${ }^{1}$ and Päivi Armila ${ }^{2}$ \\ ${ }^{1}$ South-Eastern Finland University of Applied Sciences (XAMK), Patteristonkatu 3 D, 50100 Mikkeli, Finland \\ ${ }^{2}$ University of Eastern Finland, Yliopistokatu 2, 80100 Joensuu, Finland
}

\begin{abstract}
This short paper investigates preconditions of digital agency of young people in Finland. Finland represents a society developed on digi-technological imperatives, and with young people who are considered as "digi-natives" with competences and opportunities to benefit digitalization in their everyday lives and life-courses. However, statistics still show "digital divide" and unequal sociomaterial stratification among them. To understand digital citizenship in the broadest possible sense and to empower youth as digital citizens, we need to make the inequalities visible, both at the societal, structural and life-course level.
\end{abstract}

\section{KEYWORDS}

Digital Agency, Digital Divide, Digital Natives, Finland, Youth

\section{INTRODUCTION}

The digital reality is a fundamental part of youth's everyday life: studies, work, leisure time, and activism - from personal and collective identity formations to different forms of participation (McMillan $\&$ Morrison 2006). Young people are active producers of digital youth cultures and digital contents and they actively participate in digital cultures in terms of their personal development, identity expression, and participation. Despite of all this, all socio-technical imaginaries and equality-based political promises of digitalization have not been realized among youth. Contemporary statistics in Finland inevitably prove that, in fact, there has been an increase in the number and complexity in, for example, youth's learning difficulties, even illiteracy, as well as growing inequality in welfare conditions and experiences. It is obvious that some users benefit digitalization over others (Hargittai 2008). In our paper, we argue that moving towards truly participatory digital agency requires analytic explorations of how digital information and communication technologies are implicated in social inequalities (Halford \& Savage 2010) and in digital gaps and divides. Multidisciplinary research of digital divide has brought to the fore how digital skills, digital literacy, and benefits of using digital technologies vary greatly among people. Bridging these "new" digital divides calls for understanding of "digital literacy crusaders" (Meinrath et al. 2013), as well as critical multidisciplinary analysis of inequalities created by digitalization (van Dijk 2018).

In this paper we present the conceptual background and methodological choices of our ongoing research (2020-2024) where we explore structural inequalities as lived realities by asking: What kind of differences in gender, social class, (dis)ability, religion, and ethnicity produce and maintain in young people's use of digital opportunity structures - and what kind of a "loopback" their use has to their socio-economic and socio-cultural positions, in terms of pre-existing social inequalities connected with, e.g., education and homeplace. Methodologically we stress that ethnographic approach offers a possibility to study the dynamics of digital everyday, and thus enables self-reflection of the meanings of digital possibilities as well as accumulation with other opportunities and capacities, and thereby a modern understanding of how digital agency of young people evolve. 


\section{CONCEPTUAL BACKGROUND}

Finland represents a crystallized idea of a digital society that has been developed around the ideology of technological imperatives (Talsi \& Tuuva-Hongisto 2009) and socio-technical imaginaries (Jasanoff \& Kim 2009). Technologies have been kept apart from social structures and processes, and digital ICTs are positioned as a neutral good (Halford \& Savage 2010). These logics have been seen in, e.g., a non-questioning political push towards digitalization of significant services, education, and political participation; to transform life-chances and a way to equal opportunities for social/societal participation in every corner of the society, especially among youth as "digital natives" and "cyber-children" (Prensky 2001; Tapscott 2008; Holloway \& Valentine 2003). In fact, youth seem to consider the benefits of new technology, and often they themselves are also directing the development of digitalization. They are seen as a generation who finds and adopts digital services first, and the youth-cultural meaning of digitalization is huge (Ito et al. 2010).

While youth with socio-culturally "proper" backgrounds cope well within the requirements and offerings of digitalization, the statistics show intensification of deprivation, disadvantage, and political withdrawal among those who lack the demanded socio-cultural and material resources (Statistics Finland 2016a; 2016b; 2018). In addition, digi-technological imperatives have not washed away the dividing significance of concrete homeplace spatiality in youth's life-choice possibilities concerning education, labor, leisure, and societal participation (Armila et al. 2018). Overall, today we witness a strengthening of structure-based, intersectional inequalities among youth: complex processes of socio-cultural stratification that is intertwined with material opportunities as well.

Digital agency as a methodological concept can clarify the dynamics of various connections between young people, their self and others, and the socio-cultural practices around them (Guo \& Dalli 2016). This also means that attempts to support agency must always be embedded in situations where needs and desires of young people are influenced by their learning resources, which also include places and people around them. Thus, the 'self' dimension of agency can be seen closely connected to one's socio-cultural environment. Digital agency can also be seen as a situated and contextualized dynamic process where several modalities of agency (e.g. knowing how to, being able to, having to, having the opportunity to, wanting to and feeling) needs to be possessed (Jyrkämä 2008).

Place as a significant material and socio-cultural landscape to grow up towards early adulthood is considered far too seldom in social-scientific and cultural analyses of meanings, lifestyles and life-courses (Armila et al. 2016; Armila et al. 2018). Here, we understand youth's home-places as environments with asymmetrical material, socio-cultural and youth-cultural opportunity structures. To reveal the meaning of place and regionality, three fundamentally different Finnish localities are studied in our project: remote and emptying agricultural municipality in a regional "periphery", a small working-classed and industrial town that continuously seems to lose its young population, and a growing, "youthful" city that has an image of a tempting region especially for young adults. While in 2005 there were 2500 new inhabitants born in the youthful city, the remote municipality received only 20 . In addition, the youthful city receives amounts of young movers every year, while youth of remote places often leave their homes at the age of 16, to seek educational possibilities that do not exist near them. The small town, then, appears as a place from where the young ones just want to move away, even though there are possibilities of schooling and at least low-paid working. As research sites, these three localities are chosen as cases that represent digital society differently and offer different socio-cultural, material, and physical environments for youth to grow up. In all this, the project makes use of the critical neo-materialistic perspective and brings it strongly into empirical analyses of digitalization and virtualization.

\section{METHODOLOGICAL CHOICES}

Previous research has called for more analyses on how everyday interactions and relationships influence how we see our digital selves, and research on how individual characters and structural factors shaping disadvantages come together (Helsper 2021). To answer these questions a special methodology is needed. One way to reach this in our project is to combine 'associational sociology' (Halford \& Savage 2010) and multi-sited (digital) ethnographies (Marcus 1995; Hine 2015). This combination allows a unique investigation 
of digi-natives' realities, lived youth-cultures, and divides combined with digital materialism. The critical sociological scrutiny traces the systematic and structural divisions and socio-cultural mechanisms that produce and maintain disadvantages in how digital possibility structures are and can be "capitalized" among young people.

Our approach combines qualitative and quantitative data in its analyses of digi-cultural structures, opportunities, practices, and meanings. Digital upstairs, downstairs as a sub-project drives its inspiration from a need of understanding processes that link Internet and the web to social inequality (Halford \& Savage 2010). The analytical aim is, first, to trace the unequal socio-cultural factors of the digital divide among youth, and second, to analyze the mechanisms within which they, in turn, become lived realities in young people's life-worlds and life-choices in the three different living areas. This look leans on views from critical sociology and utilizes the concept of digital opportunity structures. These contain, e.g., digital infra and access to it, but also the practice: individual, cultural, classed, and localized knowhow, and the contents, services, and preferences of digitality from the evaluative and choosy view of young informants. Concretely, a questionnaire for young participants has been developed and delivered.

The second sub-project, lived digital practices, defines young people not only as victims of unequal structures but also active agents within their social and youth-cultural environments. Their digi-cultural practices are made visible with a media ethnographic approach which enables to analyze different youth-cultural and territorialized forms in the ways young people themselves actively produce material into digital agendas and how these can be explained through the lenses of critical conceptualizations of new materialism. The aim is to understand different ways of how places traverse online/offline contexts and are collaborative, participatory, open and public (Postill \& Pink 2012). It enables to make visible connections and intra-actions between online and locality-based realities (Tuuva-Hongisto 2012). Concretely, we have made individual interviews and focus group interviews with young people to discuss what young people think about digitalization and what kind of role it has in their lives. We have also used digital ethnographic approaches to look more closely what kind of practices these young people have in digital environments.

\section{CONCLUSION}

The ethical, youth political and science political basis of youth research can be traced back to a classical theory of the German sociologists of education, Karl Mannheim (1928), who celebrated young people as a generation with a fresh contact to society and its changes. Following this, it could be reasoned that youth as a generation have no problems in dealing with today's digital opportunity structures. However, the reality seems not to be so univocal. It is obvious that we cannot separate social inequalities from spatial and technical developments.

Inequalities in a digital society have usually been studied by looking at old people as incapable to adopt the digital ways to "come along" and take care of pressing matters. In our project, we bring youth as a special target for the scrutiny of inequalities in the digital society. Young people who were born in the year 2005 can be seen as a "digital generation" and are chosen to represent the target population of this project. During the four years of this research, they will go through fundamental transitions of their life-courses concerning education, employment, moving away from their childhood families, and becoming full-aged: growing up towards emerging adulthood in economically and socio-culturally different environments, and become mature citizens of a digital society. Our study also widens the analytical discussions of digital society by taking place as a concretely significant factor and effective environment for growing up as "digital natives". Following digital threads of belonging in young people's everyday lives, we can trace and identify digital gaps that are not yet known. Virtual opportunity structures are claimed to disappear the restricting dimensions of distances and other material regional characters (e.g., unequal possibilities of education, employment, consumption, and leisure), but more research-based knowledge is needed in order to be convinced by this imaginary.

\section{ACKNOWLEDGEMENT}

DEQUAL-project is funded by the Academy of Finland (330574). 


\section{REFERENCES}

Armila, P., Halonen, T. and Käyhkö, M., 2016. Reunamerkintöjä Hylkysyrjästä. Nuorten elämää ja tulevaisuudensuunnitelmia harvaan asutulla maaseudulla. The Finnish Youth Research Society, Helsinki.

Armila, P., Käyhkö, M. and Pöysä, V., 2018. On the Educational Edges of a Learning Society. The Finnish Hinterland as a Framework of Educational Choices of Young People. The Journal of Youth Studies, Vol. 29, No. 9, pp. 1198- 1215. https://doi.org/10.1080/13676261.2018.1453128.

van Dijk, J. 2018. Afterword: the state of Digital Divide Theory. In Ragnedda, M, \& Muschert, GW (eds.) Theorizing Digital Divides. Routledge, London \& New York, pp. 199-206.

Guo, K. and Dalli, D., 2016. Belonging as a Force of Agency: An Exploration of Immigrant Children's Everyday Life in Early Childhood Settings. Global Studies of Childhood, Vol. 6, No. 3, pp. 254-267. https://doi.org/10.1177/2043610616665036

Hargittai, E., 2008. The Digital Reproduction of Inequality. In D. Grusky (ed.) Social Stratification. Class, Race, and Gender in Sociological Perspective. Routledge, London \& New York.

Halford, S. and Savage, M., 2010. Reconceptualizing Digital Social Inequality. Information, Communication \& Society, Vol. 13, No.7, pp. 937-955. https://doi.org/10.1080/1369118X.2010.499956

Helsper, E.J., 2021. The Digital Disconnect. The Social Causes and Consequences of Digital Inequalities. Sage, London.

Hine, C., 2015. Ethnography for the Internet: Embedded, Embodied and Everyday. Routledge, London \& New York.

Holloway, S.L. and Valentine, G., 2003. Cyberkids. Children in the Information Age. Routledge/Falmer, London and New York.

Ito, M. et al., 2010. Hanging out, Messing around and Geeking out: Kids Living and Learning with New Media. The MIT Press, Cambridge, Massachusetts, and London.

Jasanoff, S. and Kim, S-H., 2009. Containing the Atom: Sociotechnical Imaginaries and Nuclear Power in the United States and South Korea. Minerva, Vol. 47 No. 2, pp. 119-146. https://doi.org/10.1007/s11024-009-9124-4.

Jyrkämä, J., 2008. Toimijuus, Ikääntyminen ja arkielämä - hahmottelua teoreettis-metodologiseksi viitekehykseksi [Agency, aging, and everyday life: An outline for a theoretical-methodological framework]. Gerontologia, Vol. 4 (2002), pp. 190-203. http://urn.fi/URN:NBN:fi:ELE-1405542.

Marcus, G. E., 1995. Ethnography in/of the world system: The emergence of multi-sited ethnography. Annual Review of Anthropology, 24(1995), 95-117.

Manheim, K., 1928. The Problem of Generations. In Mannheim, K: Essays. Routledge, London.

McMillan, S.J. and Morrison, M., 2006. Coming of Age With the Internet: A Qualitative Exploration of How the Internet Has Become an Integral Part of Young People's Lives. New Media \& Society, Vol. 8 No. 1, pp. 73-95. https://doi.org/10.1177/1461444806059871.

Meinrath, S. D., Losey, J. \& Lennet B., 2013. Afterword. Internet freedom, nuanced digital divides, and the Internet craftsman. In Ragnedda, M., \& Muschert, G. W. (Eds.) The digital divide: The internet and social inequality in international perspective. Routledge, London \& New York, pp. 309-315.

Postill, J. and Pink, S., 2012: Social Media Ethnography: The Digital Researcher in a Messy Web. Media International Australia Vol. 145, No. 1. https://doi.org/10.1177/1329878X1214500114

Prensky, M., 2001. Digital Natives, Digital Immigrants. On the Horizon, Vol. 9, No. 5.

Statistics Finland 2016a; 2016b; 2018: https://www.stat.fi/index_en.html.

Talsi, N. \& Tuuva-Hongisto, S., 2009. "Ei vietetty sinä jouluna tekniikan riemujuhlaa" Teknologinen imperatiivi teknologiaelämäkerroissa. Kulttuurintutkimus, Vol. 26, pp. 71-82. http://urn.fi/URN:NBN:fi:ELE-1551839.

Tapscott, D., 2008. Grown up Digital! How the Net Generation is Changing your World. The McGraw-Hill Companies, New York.

Tuuva-Hongisto, S., 2007. Tilattuja tarinoita. Etnografinen tutkimus pohjoiskarjalaisesta tietoyhteiskunnasta. Joensuun yliopiston humanistisia julkaisuja n:o 47. Joensuu. 